\title{
DYNAMIC DIMENSIONS OF RADICALIZATION \& VIOLENT EXTREMISM IN SABAH, MALAYSIA
}

\author{
SAMUEL HENKIN
}

\section{SOUTHEAST ASIA SERIES}

${ }^{66}$ Malaysia offers a unique lens to evaluate the changing dynamics of radicalization and extremism in Southeast Asia, as the threat of both home-grown and external extremism grows.

\section{FAST FACTS}

$\rightarrow$ A regionalist approach is seminal to investigating potential threats of extremist movements in Southeast Asia.

$\rightarrow$ The tensions between and grievances formed because of actual and perceived marginalization in Sabah fundamentally shape risk factors to radicalization.

$\rightarrow$ Past geopolitical, economic, and ethno-religious relationships between the southern Philippines and Sabah shaped current violent extremist threats and risks.

$\rightarrow$ (Irregular) migration represents one of the most critical issues in

Sabah today.

\section{Context}

On May 17, 2021, Malaysian police conducted a counter-terrorism raid against suspected Abu Sayyaf Group (ASG) members in Sabah, located on the northeast portion of Malaysian Borneo. ${ }^{1}$ The police intervention resulted in the death of five suspected ASG members, including an ASG sub-commander on the Philippine government's wanted list. ${ }^{2}$ Two weeks earlier, eight suspected ASG militants were arrested in Sabah based on shared intelligence of extremist activities between the Philippine and Malaysian governments. These recent incidents echo former Inspector-General of Police Mohamad Fuzi Harun's 2019 warning that foreign militants plan to use Malaysia as a "safe haven," as well as a transit and

\footnotetext{
1 "Malaysian police kill suspected Philippine militants," The Strait Times, May 18, 2021, https://www.straitstimes.com/asia/se-asia/ malaysian-police-kill-suspected-philippine-militants. 2 Ibid.
} 
logistics center, following the territorial collapse of the Islamic State (IS). ${ }^{3}$ Three years earlier, on June 29, 2016, a bomb exploded at the Movida nightclub in Puchong, Selangor, in an IS-inspired attack carried out by two local IS supporters, a first in Malaysia.

Malaysia offers a unique lens to evaluate the changing dynamics of radicalization and extremism in Southeast Asia, as the threat of both home-grown and external extremism grows. The country's geographic location, bordering multiple active centers of violent extremism (the southern Philippines, southern Thailand, and Indonesia), makes it particularly vulnerable to further threats from violent extremism and terrorism, as regional and local violent extremist organizations (VEOs) exploit Malaysian geohistorical contexts and growing grievances related to social and political instability. ${ }^{4}$ Threats and risks of violent extremism are especially pronounced and manifest with severe consequences in the Malaysian state of Sabah.

Sabah (formally known as North Borneo) and its neighboring state Sarawak are part of the geographic region known as East Malaysia, which has significant historical, sociopolitical, and ethno-religious distinctions from West Malaysia, commonly referred to as Peninsular Malaysia, or the Peninsular, where the federal government of Malaysia is housed. Sabah's close proximity and shared borders with the southern Philippines and Indonesia greatly shapes its security vulnerabilities. Sabah suffers from decades of poor governance and lack of state capacity, economic and political marginalization, irregular migration, and proximity to violent extremist conflicts in the southern Philippines that pose great potential for radicalization and terrorist threats. Evidence suggests that Filipino VEOs, particularly ASG, exploit these insecurities and are actively radicalizing and recruiting Malaysians and Filipino expats living in Sabah. ${ }^{5}$ For example, in 2017 four individuals (two Bangladeshi nationals, a Filipino man, and a Sabahan women) were arrested for alleged ties to an IS-linked cell in the southern Philippines. ${ }^{6}$

Sabah's close proximity to the Philippines and Indonesia, combined with longstanding trade routes, porous borders, and cross-border familial ties, facilitate high levels of irregular migrant and commodities flows between countries through clandestine channels. While these clandestine channels primarily function as conduits for long-standing migration flows related to economic opportunities and chain migration, there is concern that VEOs and related criminal elements exploit the routes and the peoples taking them. According to the Global Terrorism Database (GTD), between 2000 and 2019, there were a total of 71 terrorist attacks in Sabah, of which exactly one-third (25 attacks) were associated with ASG. ${ }^{7}$ Additionally, illicit and illegal smuggling (e.g., firearms and drugs), acts of piracy, kidnapping, and extremist activities in Sabah are on the rise. ${ }^{8}$

3 Nadirah H. Rodzi, "Kuala Lumpur says foreign militants eyeing Malaysia as safe haven," The Strait Times, March 11, 2019, https://www.straitstimes.com/asia/se-asia/kl-says-foreign-militantseyeing-malaysia-as-safe-haven.

4 Samuel Henkin, Marcus A. Boyd, and Adam Martin, "Southeast Asia After the Caliphate: Identifying Spatial Trends in Terrorism and Radicalization in Malaysia," Statistics, Politics and Policy (2020), https://doi.org/10.1515/spp-2020-0001.

5 Shashi Jayakumar, "The Islamic State Looks East: The Growing Threat in Southeast Asia," CTC Sentine/ 22 (2017), https://www. ctc.usma.edu/the-islamic-state-looks-east-the-growing-threat-in-southeast-asia/.

6 Teoh Pei Ying, "12 Filipinos, one Malaysian terror suspects nabbed in Sabah crackdown," New Straits Times, March 18, 2019, https://www.nst.com.my/news/crime-courts/2019/03/470376/12-filipinos-one-malaysian-terror-suspects-nabbed-sabahcrackdown.

7 "Global Terrorism Database (GTD)," The National Consortium for the Study of Terrorism and Responses to Terrorism (START) at the University of Maryland, College Park. Accessed August 15, 2021, https://start.umd.edu/gtd/.

8 The most significant cross-border attack example, the Tanduo Incident or Lahad Datu standoff, occurred April 2013 where over 200 Royal Sulu Army (RSA) militants and followers of a claimant to the sultanship of Sulu invaded eastern Sabah using 
This policy note advances a granular review of the dynamics underlying radicalization risk in Sabah, Malaysia, in order to extrapolate an analysis of emerging areas of threat and risk of violent extremism facing Southeast Asia. It offers an opportunity to better understand current and future threats and risks of violent extremism facing Southeast Asia and identifies important trends and recommendations for policymakers and practitioners in mitigating the spread of violent extremism and radicalization to violence in Sabah. The policy note also considers how building local preventing and countering violent extremism (P/CVE) capacity can mitigate Malaysia's role as a staging area, transit hub, and conduit for the transportation of weapons, operatives, finances, and supporters to other regional and global terrorist organizations. ${ }^{9}$

\section{Relevance to Policy and Practice}

Terrorism and violent extremism in Southeast Asia are highly complex phenomena, involving diverse groups with different origins, ideologies, and causes. As a resurgent tide of extremist movements burgeons with destabilizing effects on civil societies across Southeast Asia, radicalization and recruitment to extremist violence are widely acknowledged as a defining societal challenge among Southeast Asian states. Failure to meet the challenge of violent extremism has significant real-world consequences. Moreover, Southeast Asia is a region of the world where past failures to meet the challenge of violent extremism resulted in a resurgence of violent extremist activity, including acts of terrorism, built upon the legacies of some of the world's oldest and most active VEOs. ${ }^{10}$

Varying degrees of weak governance with high levels of political instability and porous border regions, coupled with existing security and social vulnerabilities draw attention to the dynamic dimensions of radicalization and violent extremism risk in Southeast Asia, particularly related to militant and extremist Islam. Refocusing strategic attention to supporting local capacities to mitigate a persistent regeneration of regional and local VEOs can assist in eliminating terror cells and countering radicalization narratives in Southeast Asia, including in Malaysia. ${ }^{11}$

Despite the comparative rarity of terrorist attacks in Malaysia to date, since 2013 the Malaysian government revealed that over one hundred Malaysians had joined the ranks of IS in Syria and Iraq. ${ }^{12}$ Though only a handful have returned, radicalization and recruitment to violence remain a risk in Malaysia, as evidenced by more than 430 terror-related arrests since 2013 and, relatedly, the foiling of over 30 Malaysian terror plots. ${ }^{13}$ Moreover, while Malaysia has experienced relatively

clandestine channels.

9 Andrin J. N. Raj, "Challenges in counter terrorism and counter violent extremism in Malaysia," in Countering Insurgencies and Violent Extremism in South and South East Asia, ed. Shanthie Mariet D'Souza (New York: Routledge, 2019), $207-222$.

10 See: Joseph Chinyong Liow, "Shifting Sands of Terrorism in Southeast Asia," RSIS Commentaries, No. 025, February 15, 2018, https://www.rsis.edu.sg/rsis-publication/rsis/co18025-shifting-sands-of-terrorism-in-southeast-asia/\#.Ya-Ifr3MLfY; John Sidel, The Islamist Threat in Southeast Asia: A Reassessment (Washington, DC: East-West Center, 2007), https://www.eastwestcenter.org/publications/islamist-threat-southeast-asia-reassessment; Zachary Abuza, Militant Islam in Southeast Asia: Crucible of Terror (Boulder, CO: Lynne Rienner, 2003).

11 Kumar Ramakrishna, "'The Southeast Asian Approach' to Counter-Terrorism: Learning from Indonesia and Malaysia," The Journal of Conflict Studies 25, no. 1 (2005): 27-47, https://journals.lib.unb.ca/index.php/JCS/article/download/189/333?inline=1.

12 Mohamed Nawab Mohamed Osman and Aida Arosoai, "Jihad in the Bastion of 'Moderation': Understanding the Threat of ISIS in Malaysia," Asian Security 16, no. 1 (2019): 1-14, https://doi.org/10.1080/14799855.2018.1470508. 
low incidents of terrorism, research suggests that there are higher levels of radicalization in Malaysian society compared to most in the region. ${ }^{14}$ Just six years ago, a Pew Research survey discovered that while a majority of Malaysians surveyed expressed unfavorable views of IS (64 percent), 11 percent of Malaysians expressed "favorable" views towards IS, the fourth highest among Muslim-majority countries. ${ }^{15}$ Coupled with aggressive recruitment techniques and a wave of online propaganda targeting Malaysians, the emergence of a "virtual caliphate" with increasing positive sentiment of extremist ideology in Malaysia is of significant concern. ${ }^{16}$

In the past, Sabah was used as a staging area where regional VEOs, like Jemaah Islamiyah (JI), trained and coordinated attacks. ${ }^{17}$ Today, VEOs not only use Sabah as a transit point but also actively exploit its unique geohistorical circumstances, clandestine flows, and ethno-religious grievances to radicalize and recruit impressionable Malaysians and Filipino expatriates living in Sabah. Enhanced understanding of broader historical, geopolitical, and social dynamics of radicalization in Sabah will illustrate the importance of Malaysia's role in Southeast Asian experiences of radicalization and terrorism. Moreover, exploring the nuances of violent extremism and terrorism impacting Sabah affords an opportunity to tease apart ties among VEOs, ideological cross-fertilization and competition, and the recent impact of transnational interests proliferating across the region reshaping the landscape for both counterterrorism (CT) and preventing and countering violent extremism (P/CVE).

\section{Key Insights and Recommendations}

Four overarching areas of political significance-geohistorical contexts, Malaysian ethnoreligious policy, irregular migration and clandestine channels, and Philippine VEOs' exploitation of Philippine-Sabah dynamics - are of increased importance to prevent and counter the spread of violent extremist ideology in Malaysia. Each of these areas and policy recommendations relevant to addressing them, are expanded upon below.

\section{The influence of geohistorical contexts}

Violent extremism in Southeast Asia is deeply rooted in the historical legacies of the struggle to determine the role of Islam in society, dating back to post-colonial state-building. The legacies of this struggle continue to shape Islamist identities and radicalization into extremism across the region today. ${ }^{18}$ The trajectory of militant Islam and its propensity to drive violent extremism in the region continues to have the potential to aggravate political and religious tensions straining the region's complex social fabric. For example, ethno-nationalist Islamic insurgencies in southern Philippines and southern Thailand garner broader support for a more militant Islamist agenda, as

14 Nicholas Chan, "The Malaysian 'Islamic' State versus the Islamic State (IS): evolving definitions of 'terror,' in an 'Islamising" nation-state," Critical Studies on Terrorism, 11, no. 3 (2018): 415-437, https://doi.org/10.1080/17539153.2018.1447217. Ibid., 415.

Rashvinjeet S. Bedi, "One in five Malaysian undergrads feel terrorism an effective tool for achieving objectives, say survey," The Star Online, July 27, 2018, https://www.thestar.com.my/news/nation/2018/07/27/ one-in-five-msian-undergrads-feel-terrorism-effective-tool-for-achieving-objectives/.

17 Kristen E. Schulze and Julie Chernov Hwang, "Militant Islam in Southeast Asia: New Insights into Jihad in Indonesia, Malaysia and the Philippines," Contemporary Southeast Asia 41, no. 1 (2019): 4, https://doi.org/10.1355/cs41-1a.

Schulze and Chernov Hwang, "Militant Islam in Southeast Asia." 
sympathy for the plight of Muslim minorities constructs Islamist narratives (and identities) around grievances, representation, and self-autonomy across the region. However, there is no neat pattern of radicalization into violent extremism in Southeast Asia. Differences among peoples, nations, groups, and grievances all espouse different motivations, regardless of ties among militant Islamist extremist groups in the region.

Therefore, a regionalist approach, which privileges an evaluative lens on complex local contexts (e.g., history, geography, local social and political relations) is seminal to investigating potential threats of extremist movements in Southeast Asia. ${ }^{19}$ Rather than understanding regional and local extremist movements as part of a broader shared transnational jihadism, a regionalist approach teases out a more nuanced understanding of varying strains of militant Islam. Simply put, this approach looks past common assumptions underpinning the current confluences of the violent extremist threat landscape and offers different explanations that are historically and socially grounded for the varying levels of vulnerability to extremist ideologies and violent extremist activity across Southeast Asia.

A regionalist approach to understanding violent extremism in Southeast Asia recognizes that the types, actors, and principal motivations vary widely but are sustained in regional and local contexts. Moreover, these contexts constitute an "enabling environment" where radicalization into violent extremism draws on a multiplicity of motivational factors that in the past led to the rise (and fall in some instances) of regional VEOs like Jemaah Islamiyah (JI), Kumpulan Mujaheddin Malaysia (KMM), ${ }^{20}$ Moro Islamic Liberation Front (MILF), and Abu Sayyaf Group (ASG). ${ }^{21}$ Today, vestiges of existing extremist networks of diverse regional and local VEOs are reenergized and highly sympathetic to transnational militant Islamist causes declaring Bay'ah ${ }^{22}$ to transnational terrorist organizations, like the Islamic State (IS) and al-Qaeda (AQ). Still, their desire to bolster connections and project strength is innately rooted in their local and regional objectives. ${ }^{23}$

Recommendation: Adopt a regionalist approach that examines regional extremist movements as products of local historical, socio-cultural, and political dynamics, not mere products of transnational jihadi activity.

Applying a regionalist approach to violent extremism in Malaysia offers crucial insights:

$\rightarrow$ Malaysians are more likely to be vulnerable to extremist ideologies related to actual and perceived persecution of fellow Muslims in active centers of violent extremism along their borders (the Philippines and Thailand).

$\rightarrow$ While Malaysia primarily serves as a logistic and transit hub for regional and transnational

19 Ibid.

20 Originally known as Kumpulan Mujahidin Malaysia, the group was later renamed Kumpulan Militant Malaysia by both the Malaysian security agencies and the media.

21 Paul J. Smith (ed), Terrorism and Violence in Southeast Asia: Transnational Challenges to States and Regional Stability (London: Routledge, 2005), xii.

22 Bay'ah or Bai'at is an Islamic practice of declaring an oath of allegiance to a leader.

23 Ramli Dollah, Wan Shawaluddin Wan Hassan, Diana Peters, and Zaini Othman, "Old Threats, New Approach and National Security in Malaysia: Issues and Challenges in Dealing with Cross-border Crime in East Coast of Sabah," Mediterranean Journal of Social Sciences 7, no. 3 (2016): 178-186, https://doi.org/10.5901/mjss.2016.v7n3s1p178. 
VEOs, radicalization patterns suggest a burgeoning domestic extremism base.

$\rightarrow$ The politicization of Islam has had polarizing effects in the multi-ethnic and multicultural communities of Malaysia, thereby escalating confrontations between Muslims and nonMuslims in Malaysia.

$\rightarrow$ Malaysia maintains aggressive CT practices that have largely proven to be effective at taking various steps to mitigate and prevent the threats of terrorism. However, as extremist and radicalization narratives take to the internet, more effective holistic P/CVE efforts must be considered in Malaysia.

\section{Regional differences and the Malaysian ethno-religious policy}

As the threat of militant Islam and radicalization into extremism engenders concern in Malaysia, sweeping P/CVE efforts lack basis to address the varied risk factors for violent extremism that differ between Peninsular Malaysia and Sabah. The level of intensity of the threat of violent extremism and vulnerabilities to radicalization in Malaysia are far more prevalent in Sabah as evidenced by the legacies of historic and ongoing violent extremist activities and terrorist attacks. ${ }^{24}$ Therefore, understanding that vulnerabilities to, and actual acts of, violent extremism are experienced unevenly across Malaysia needs to drive more nuanced P/CVE efforts.

Broadly speaking, the threat of violent extremism and terrorism in Malaysia is differentiated by the geohistorical and ethno-religious identity differences between Peninsular Malaysia and East Malaysia. East Malaysia, especially Sabah, sustains unique and shared socio-political, ethnoreligious, and economic characteristics that shape their relationships with neighboring states (the Philippines and Indonesia), including higher levels of violent extremist activity and therefore increased exposure to potential radicalization pathways. ${ }^{25}$ Of significant concern in Malaysia is how ethno-religious policies manifest differently in the Peninsular and Sabah, where increased feelings of marginalization and grievance coalesce alongside steady levels of foreign migration (both regular and irregular). The steady increase in migration is due to years of violent conflict and extremist activity in the southern Philippines that has gradually reshaped the ethno-religious and cultural landscapes, adding further complexity to social, political, and economic relations in Sabah.

Malaysia's ethno-cultural and political landscapes have become more complex with the rise of Islam and its continued political institutionalization. As ethno-religious politics plays out, there is increasing fear of assimilation by the Sabahan people through the ongoing politicization of Islamthe "Malayization" or "Islamization" project-practiced by the federal Malaysian government and state leaders in Peninsular Malaysia. ${ }^{26}$ Malaysian ethno-religious politics categorizes citizens along religious (Muslim and non-Muslim) and ethnic (Malay [Bumiputera] and non-Malay [non-

24 Global Terrorism Database, 2021.

25 Risk factors for radicalization to violent extremism are dynamic and have generated numerous, and sometimes contradictory, characteristics. However, studies show that sociodemographic characteristics in combination with other factors (e.g., psychological) correlate with engaging violent extremism.

26 Joseph Chin Yong, Piety and politics: Islamism in contemporary Malaysia (Oxford University Press, 2009), https://doi. org/10.1093/acprof:oso/9780195377088.001.0001. 
Bumiputera or non-Bumis]) lines as stated in the Federal Constitution of Malaysia. ${ }^{27}$ Ethno-religious policies are far more complex in Sabah as both the Bumiputera and non-Bumiputera populations are highly heterogeneous.

In Sabah, within the Bumiputera status, there are two different groups comprised of MuslimBumis and non-Muslim Bumis. The non-Muslim Bumis population includes Sabah's indigenous populations, including the Kadazan-Dusun, a coalition of indigenous groups that now form the largest indigenous population in Sabah. The Muslim-Bumis population also includes significant ethnic group heterogeneity with such diverse populations as the Bajau, Suluk, Illanun, Kedayan, and Brunei Malay. While ethno-religious politics in Peninsular Malaysia stress differences between Bumiputera and non-Bumiputera, in Sabah the differences between Muslim Bumis and nonMuslim Bumis is most significant. Muslim-Bumis in Sabah are offered special societal and economic privileges through a race-based quota system, whereas non-Muslim Bumis are not afforded the same opportunities. ${ }^{28}$ The legacies of competition and rivalry between Muslim-Bumis and nonMuslim Bumis populations continue to contour the politics of Sabah today.

Recommendation: Understand that risk factors for violent extremism differ in Peninsular Malaysia and Sabah.

Risk factors for violent extremism differ in Peninsular Malaysia and Sabah. As such, policy and programmatic efforts must take into account the following:

$\rightarrow$ As the processes of Malayization and Islamization in Peninsular Malaysia has become increasingly legitimized in national politics, it has made way for a rise in Sabahan regionalism to counter the impacts.

$\rightarrow$ The tensions between and grievances formed because of actual and perceived marginalization in Sabah fundamentally shape risk factors to radicalization into violent extremism in Sabah.

$\rightarrow$ The current rise of Sabahan regionalism sheds light on the deepening ethno-religious divides in Sabah, as well as Malaysia more generally.

$\rightarrow$ Fundamentally, in understanding that risk factors for violent extremism differ in Peninsular Malaysia and Sabah, it is vital to address the increasing Islamization of Malaysia and its impact on Sabah's majority non-Muslim Bumis.

\section{Irregular migration and clandestine channels into Sabah}

Historically, time-honored trade routes, geographical proximity, and close, cross-border familial ties facilitated highly unregulated migrant flows throughout the Sulu-Celebes Sea and tri-border

27 Bumiputera, comprising Malays and natives of Sabah and Sarawak, are offered special societal and economic privileges in accessing a range of services and opportunities, including public-sector jobs, business licenses, and government contracts. In contrast, non-Bumiputera, such as Malaysia's large Chinese population and other non-indigenous peoples, do not have the same opportunities.

28 Vejai Balasubramaniam, "A divided nation: Malay political dominance, Bumiputera material advancement and national identity in Malaysia," National Identities 9, no. 1 (2007): 35-48, https://doi.org/10.1080/14608940601145679. 
region (Sabah, southern Philippines, and Indonesia). Over the years, growth in economic opportunities in Sabah, increased levels of violence and instability in the southern Philippines (and Indonesia), and chain migration as a result of blending ethno-identity, culture, and religion have generated problematic migration regulation in Sabah. As such, (irregular) migration is one of the most critical issues in Sabah today. ${ }^{29}$ Of significant concern for Sabah are: 1) poor border regulation along its porous land and sea borders; 2) significant numbers of clandestine cross-border channels; 3) weak enforcement of migration policies, particularly overstaying visas; and 4) the necessity of foreign laborers for Sabah's low-skilled and labor-intensive economic sectors. ${ }^{30}$

As irregular migration continues to increase, significant social implications arise, since irregular migrants, mostly looking for economic opportunities in Sabah, actively work to avoid detection. In the process of avoiding detection, a vast amount of irregular migration in Sabah occurs through clandestine cross-border channels, or jalan tikus ("mouse paths"). ${ }^{31}$ These clandestine routes that incorporate complex waterways and jungle paths along Sabah's porous border prove highly difficult to monitor. Although these clandestine routes are legacies of transnational kinship networks and longstanding patterns of migratory movement and trade, increases in illicit and illegal services (e.g., fake document syndicates) and smuggling activities (e.g., weapons and drugs) actively exploit these clandestine channels as well. ${ }^{32}$ There are noteworthy security concerns that VEOs also exploit clandestine channels indicated by a rise in acts of piracy, kidnapping for ransom $(K f R)$, and territorial incursions in an effort to generate funds and facilitate terror (e.g., Tanduo Incident, or 2013 Lahad Datu standoff).

Recommendation: Discontinue narratives blaming irregular migration for increasing violent extremist activities in Sabah.

In political and public discourse irregular migration in Sabah is often pejoratively linked to violent extremism and increasing criminal activities. Regardless of the real threats posed by the network of clandestine channels and their growing shadow economies, narratives that blame irregular migration for increasing violent extremist activities in Sabah lack credible evidence. Discontinuing these narratives in Sabah recognizes the following:

$\rightarrow$ Narratives that blame irregular migrants, especially Filipinos, work against P/CVE efforts in Sabah as they reify in-group/out-group biases, a fundamental characteristic of radicalization into extremism that negatively influences migrant communities in Sabah.

$\rightarrow$ Negative impacts from narratives that blame irregular migration enhance grievances experienced by marginalized communities in Sabah and potentially offer pathways to more extremist ideologies espoused by extremist groups in the region.

29 There are an estimated 1.2 to 1.5 million irregular migrants in Sabah.

30 Mauro Testaverde, Harry Moroz, Claire H. Hollweg, and Achim Schmillen, Migrating to opportunity: Overcoming Barriers to Labor Mobility in Southeast Asia (Washington, D.C.: The World Bank, 2017), https://openknowledge.worldbank.org/ handle/10986/28342.

31 Andrew M. Carruthers, Clandestine Movement in the Indonesia-Malaysia Migration Corridor: Roots, Routes, and Realities (ISEAS Yusof Ishak Institute, 2017), http://hdl.handle.net/11540/7362.

32 Ibnor Azli Ibrahim, Mohd Nur Hidayat Hasbollah Hajimin, Ezad Azraai Jamsari, Badlihisham Mohd Nasir, and Mohd Hafiz Safiai, "The Impact of Filipino Muslim Ethnic Migration into Sabah on ASEAN Integration," International Journal of Innovative Technology and Exploring Engineering 8, no. 11 (2019): 369-372, https://doi.org/10.35940/ijitee.k1354.0981119. 
$\rightarrow$ The threat of Filipino VEOs actively engaging in radicalizing and recruiting Malaysians and Filipino migrants living in Sabah is of concern, as the influence of extremist ideology in the region grows. ${ }^{33}$

Recommendation: Improve understanding of the operations of clandestine channels to strengthen the ability to detect, disrupt, and dismantle them.

A more fruitful approach to mitigating the dynamics undergirding radicalization risk in Sabah is to enhance research and operational understanding of clandestine channels and mobility. Effectively integrating socio-political, economic, and ethno-religious knowledge bases related to these long-standing migrant and economic flows can offer methods and strategies to better detect, disrupt, and dismantle nefarious and violent exploitation of these routes. The Eastern Sabah Community Command (ESSCOM) tasked with operational security in the Eastern Sabah Security Zone (ESSZONE) related to acts of maritime violence, irregular migration, militant and extremist activities, and related organized criminal activities must better address the multiple uses and realities of clandestine channels and migrant movement into Sabah. The following insights are instructive for efforts to better address clandestine channels and migrant movement:

$\rightarrow$ Mitigating the flow of irregular migration is less critical from a security concern. The reality of cross-border migration and affiliated smuggling activities along Sabah's borders are often understood as ordinary economic activities as a result of generational transnational kinship networks and patterns of mobility. ${ }^{34}$

$\rightarrow$ Operational strategies that distinguish between these banal activities and the real threat of clandestine movement and flows that are advantageous for violent extremist and criminal organization exploitation must be considered.

$\rightarrow$ The ease with which violent extremists from the southern Philippines exploit clandestine channels, with special reference to the issues of $\mathrm{KfR}$, encroachment, and international smuggling, makes clear that Sabah is not only a transit point for Filipino VEOs but also a potentially viable mechanism for recruiting and radicalizing Malaysians and Filipino expats living in Sabah.

\section{Philippine VEO exploitation of Philippines-Sabah dynamics}

Past geopolitical, economic, and ethno-religious relationships between the southern Philippines and Sabah shaped the current threat and risk of violent extremism in the region. The political instability derived from the deep-rooted insurgent fight for self-determination and direct armed conflict between the diverse movements of Bangsamoro ${ }^{35}$ and the government of the Philippines has impacted the security situation in Sabah. Since the 1960s, the conflict between the government of the Philippines and Bangsamoro evolved from separatists' civil conflict and militant insurgencies

33 Renato Cruz De Castro, "The Influence of Transnational Jihadist Ideology on Islamic Extremist Groups in the Philippines: The Cases of the Abu Sayyaf Group and the Rajah Solaiman Movement," Public Organization Review 3, no. 4 (2003): 388.

34 Carruthers, Clandestine Movement in the Indonesia-Malaysia Migration Corridor.

35 "Bangsamoro," a portmanteau, is an ethno-political designation for the political consciousness and movement for a nation ("Bangsa") of Muslims ("Moro") in Mindanao. 
to its current incarnation, typified by violent extremist and terrorist campaigns. ${ }^{36}$ These various iterations of political violence, which produced political instability in the southern Philippines, created security vulnerabilities in Sabah as a result of spillover effects. ${ }^{37}$

Today Sabah faces a range of security challenges as a result of active Filipino VEOs exploiting various vulnerabilities. First and foremost, VEOs in the territorial waters of the Sulu-Celebes Sea between Sabah and the southern Philippines engage in advanced forms of maritime violence, including piracy and KfR. Since 2013, International Maritime Bureau (IMB) data shows that these territorial waters are the most pirate-prone in the world, and incidents of piracy continue to rise. ${ }^{38}$ There are varying forms of piracy violence in the Sulu-Celebes Sea, including harbor and anchorage attacks, ransacking and robbery of vessels, and hijacking vessels on the high seas. ${ }^{39} \mathrm{KfR}$ as a form of maritime violence is also on the rise in the region. ${ }^{40}$ While KfR sustains a long regional history, it re-emerged as a security challenge in April 2000 when six ASG militants seized 21 hostages (majority foreign nationals) from a resort on the Sabahan island of Sipadan. ${ }^{41}$ The Sipadan KfR was momentous because it exposed the fact that violent extremists in the region had the capacity to engage in highly coordinated, cross-border activities. While there have been a series of high profile KfRs involving foreign nationals since 2000, local residents in the tri-border region are the most frequent victims. ${ }^{42}$

Recommendation: Enhance cross-border collaborative maritime security infrastructure that can reduce maritime violence, including piracy and kidnapping for ransom, and acts of terror.

The dividing lines between piracy, $K f R$, and violent extremist activities are blurred in the region. Attacks are conducted by VEOs, such as ASG, but also a range of pirate gangs and so-called "kidnap-for-ransom-syndicates" that may or may not be affiliated with VEOs. ${ }^{43}$ The diffuse nature of maritime violence actors in the region make security interventions difficult to implement, still:

$\rightarrow$ Regardless of the complicated nature of policing the waterways in the Sulu-Celebes Sea with its numerous proximate islands, inlets, reefs, and international waterways, enhanced regional maritime security collaboration between Malaysia, the Philippines, and Indonesia has the potential to reduce maritime violence and should be a priority.

36 Carmen A. Abubakar, "A never-ending war and the struggle for peace in southern Philippines," in Islam and Politics in Southeast Asia, ed. Johan Saravanamuttu (Routledge, 2009), 143-159.

37 Tony Addison and S. Mansoob Murshed, "Transnational terrorism as a spillover of domestic disputes in other countries," Defence and Peace Economics 16, no. 2 (2005): 69-82, https://doi.org/10.1080/10242690500070078.

38 Ibid

39 Peter Chalk, "Contemporary maritime piracy in Southeast Asia," Studies in Conflict \& Terrorism 21, no. 1 (1998): 87-112, https://doi.org/10.1080/10576109808436055.

40 Mohd Kassim Noor Mohamed, "Kidnap for Ransom in South East Asia," Asian Journal of Criminology 3, no. 1 (2008): 61-73, https://doi.org/10.1007/s11417-007-9040-1.

41 Thomas Fuller, "20 Kidnapped from Malaysian Resort Island," The New York Times, April 25, 2000, https://www.nytimes. com/2000/04/25/news/20-kidnapped-from-malaysian-resort-island.html.

42 Eduardo F. Ugarte and Mark Macdonald Turner, "What Is the 'Abu Sayyaf'? How Labels Shape Reality," The Pacific Review 24, no. 4 (2011): 397-420, https://doi.org/10.1080/09512748.2011.596558.

43 Ibid. 
$\rightarrow$ The recently launched Trilateral Maritime Patrols (TMP) initiative has improved communication and intelligence exchange between Malaysia, the Philippines, and Indonesia and serves as an illustrative example for future policy efforts. ${ }^{44}$

\section{Conclusion}

Beyond the four areas detailed above, broadly speaking, the two major security threats facing Sabah are the ongoing exploitation of existing socio-political, ethno-religious, and geographic vulnerabilities by VEOs and the growing presence of online radicalization informed by transregional and transnational militant Islamist ideology, particularly related to IS and affiliates. It is likely that both will impact radicalization patterns in Sabah.

There is a complex layering to the unpredictable security situation in Sabah, especially now that the COVID-19 pandemic has introduced increased stressors in the region. First, geopolitical tensions between Malaysia, the southern Philippines, and Indonesia make security coalitionbuilding challenging. Second, increased stresses in federal-state relations between East and West Malaysia escalates existing grievances in Sabah as Kuala Lumpur continues to consolidate political, ethno-religious, and economic power. Third, the increasingly transnational and transregional nature of violent extremism filtering into Malaysia solidifies ties to VEOs in the region, particularly the southern Philippines, and the world. Ultimately, addressing these issues will necessitate not only some of the recommendations detailed above but also the prioritization of efforts to build local P/CVE research capacity.

If we engage a regionalist approach to better understand violent extremism that takes into account that drivers and causal structures of violent extremism are multidimensional, then, as in any region or geographic context, efforts to prevent and counter violent extremism require local nuanced understandings. A regionalist approach in Malaysia and South East Asia more broadly necessitates local research capacity. There is no "one-size-fits-all" P/CVE model. An emergent consensus in P/ CVE practice recognizes that an underlying theory of change that draws upon approaches aimed to increase local community capacity to resist and mitigate extremist violence demonstrates the potential for greater impact (local-sensitive models). ${ }^{45}$ Local-sensitive models, also commonly referred to as community-based models, understand that if diverse stakeholders are better equipped to develop community-oriented plans for building local coalitions to address P/CVE and promote community resilience, their programs are more likely to be accepted by their communities. Greater acceptance can lead to success in preventing and countering radicalization and promoting disengagement and de-radicalization. At the community level, investing in local partners facilitating a stronger coalition of diverse stakeholders will increase resilience in the event of extremist violence.

44 Ian Storey, Trilateral Security in the Sulu-Celebes Seas: A Work in Progress (ISEAS Yusof Ishak Institute, 2018), https://www. iseas.edu.sg/images/pdf/ISEAS Perspective 2018 48@50.pdf.

45 Elizabeth Hume and Emily Myers, Peacebuilding Approaches to Preventing and Countering Violent Extremism: Assessing the evidence for key theories of change (Wahsington, D.C.: Alliance for Peacebuilding, 2018), https://allianceforpeacebuilding. squarespace.com/afp-publications/peacebuilding-approaches-to-4-2018; Caitlin Mastroe and Susan Szmania, Surveying CVE Metrics in Prevention, Disengagement, Deradicalization Programs (College Park, MD: National Consortium for the Study of Terrorism and Responses to Terrorism, 2016), https://www.start.umd.edu/pubs/START SurveyingCVEMetrics March2016. pdf. 
Despite the proliferation of P/CVE programming globally, the field has been criticized for being externally imposed with competing conceptual and practical implementation. ${ }^{46}$ In other words, there is a flawed assumption in P/CVE practice that what works in one context can work in another. Local research partners embedded in the local context with vested interests and indepth knowledge of the trends and dynamics related to areas of concern are best positioned to determine and define the scope of intervention.

From experience, ${ }^{47}$ building local P/CVE research capacity is valuable in the following ways:

$\rightarrow$ Local research capacity-building aims to minimize over-reliance on outside experts as sources of knowledge, resources, and solutions to specifically local issues.

$\rightarrow$ Local research capacity-building is sensitive to the specificities of local context, which affords an opportunity to tailor theories of change appropriately around the lived experiences of communities.

$\rightarrow$ Local capacity-building strengthens research skills and ensures sustainability by investing in stakeholders with intimate knowledge and experience in the local context.

Overall, the greatest value of P/CVE practice is engendered through the sustainability of broader community resiliency and social cohesion. Sustainability through P/CVE research capacity-building rests in fostering human capital and shared knowledge that will develop local community capacity to continue best practices and reinforce local-sensitive program objectives in perpetuity. Developing these partnerships and skills are crucial to addressing violent extremism and radicalization trends in Sabah and around the world.

46 Jessica Wolfendale, "Terrorism, Security, and the Threat of Counterterrorism," Studies in Conflict \& Terrorism 30, no. 1 (2007): 75-92, https://doi.org/10.1080/10576100600791231; J. M. Berger, Making CVE Work: A Focused Approach Based on Process Disruption (International Centre for Counter-terrorism- The Hague, 2016), http://dx.doi.org/10.19165/2016.1.05.

47 Samuel Henkin, Hafiza Nur Adeen Nor Ahmad, Ramli Dollah, Wan Shawaluddin Wan Hassan, Jagroop Singh, and Ahmad elMuhammady, Divergent Dimensions of Radicalization Risk: Migration and Violent Extremism in Sabah, Malaysia, Desk Study Report to the Bureau of Conflict and Stabilization Operations, U.S. Department of State (College Park, MD: START, 2020), https:// www.start.umd.edu/publication/divergent-dimensions-radicalization-risk-migration-and-violent-extremism-sabah-malaysia. 


\section{SUGGESTED FURTHER READING}

For those interested in learning more or delving into the topic in more depth, please see the additional recommended sources/works based on key topics engaged in this policy note.

\section{On radicalization to violent extremism}

Berger, J.M. Extremism. MIT Press, 2018.

DuBois, David L., and Fasika Alem. Mentoring and domestic radicalization. National Mentoring Resource Center Research Review, 2017. https://nationalmentoringresourcecenter.org/resource/ mentoring-and-domestic-radicalization/.

Jensen, Michael A., Anita Atwell Seate, and Patrick A. James. "Radicalization to violence: A pathway approach to studying extremism." Terrorism and Political Violence 32, no. 5 (2020): 1067-1090. https:// doi.org/10.1080/09546553.2018.1442330.

Kruglanski, Arie W., Michele J. Gelfand, Jocelyn J. Bélanger, Anna Sheveland, Malkanthi Hetiarachchi, and Rohan Gunaratna. "The psychology of radicalization and deradicalization: How significance quest impacts violent extremism." Political Psychology 35, no. 1 (2014): 69-93. https://doi.org/10.1111/ pops.12163.

McCauley, Clark, and Sophia Moskalenko. "Understanding political radicalization: The two-pyramids model." American Psychologist 72, no. 3 (2017): 205-216. https://doi.org/10.1037/amp0000062.

\section{On terrorism and counterterrorism policy in Southeast Asia:}

Abuza, Zachary. Militant Islam in Southeast Asia: Crucible of Terror. Boulder, CO: Lynne Rienner, 2003.

Bakashmar, Muhammad. "Winning the battles, losing the war? An assessment of counterterrorism in Malaysia." Terrorism and political violence 20, no. 4 (2008): 480-497. https://doi. org/10.1080/09546550802257200.

Inoguchi, Takashi. Reflections on the Tenets of Foreign Policy of Southeast Asian States. (Singapore: Rajaratnam School of International Studies, Nanyang Technological University, 2021). https://www.rsis.edu. sg/wp-content/uploads/2021/06/CER210629 Reflections-on-the-Tenets-of-Foreign-Policy-of-Southeast-Asian-States.pdf.

Schulze, Kristien E., and Julie Chernov Hwang. "Militant Islam in Southeast Asia." Contemporary Southeast Asia 41, no. 1 (2019): 1-13.

Terrorism and Counterterrorism in Southeast Asia: Emerging Trends and Dynamics. The Soufan Center, June 2021. https://thesoufancenter.org/research/terrorism-and-counterterrorism-in-southeast-asiaemerging-trends-and-dynamics/.

White, Gentry, Michael D. Porter, and Lorraine Mazerolle. "Terrorism risk, resilience and volatility: A comparison of terrorism patterns in three Southeast Asian countries." Journal of Quantitative Criminology 29, no. 2 (2013): 295-320. https://doi.org/10.1007/s10940-012-9181-y. 
On violent extremism in Sabah, Malaysia

Febrica, Senia. "Securing the Sulu-Sulawesi Seas from Maritime Terrorism: a Troublesome Cooperation?." Perspectives on Terrorism 8, no. 3 (2014): 64-83.

Henkin, Samuel, Hafiza Nur Adeen Nor Ahmad, Ramli Dollah, Wan Shawaluddin Wan Hassan, Jagroop Singh, and Ahmad el-Muhammady. Divergent Dimensions of Radicalization Risk: Migration and Violent Extremism in Sabah, Malaysia, Desk Study Report to the Bureau of Conflict and Stabilization Operations, U.S. Department of State. College Park, MD: START, 2021. https://www.start.umd.edu/publication/ divergent-dimensions-radicalization-risk-migration-and-violent-extremism-sabah-malaysia.

Low, Choo Chin. "Extraterritorial migration control in Malaysia: Militarized, externalized, and regionalized." Regions and Cohesion 9, no. 3 (2019): 1-28. https://go.gale.com/ps/i.do?id=GALE\%7CA673438 $\underline{030 \& \text { sid }=\text { googleScholar } \& v=2.1 \text { \& } i t=r \& \text { linkaccess }=a b s \& i s s n=2152906 X \& p=A O N E \& s w=w \& u s e r G r o u p N}$ ame=anon\%7E84361aa3.

Singh, Bileveer, and Jasminder Singh. "From 'bandit' to 'Amir' - The Rise of the Abu Sayyaf Group as a Jihadi Organization in the Philippines." Asian Politics \& Policy 11, no. 3 (2019): 399-416. https://doi. org/10.1111/aspp.12480.

On migration in the tri-border (Malaysia, Indonesia, Philippines)

Dollah, Ramli, and Kamarulnizam Abdullah. "The securitization of migrant workers in Sabah, Malaysia." Journal of International Migration and Integration 19, no. 3 (2018): 717-735. https://doi.org/10.1007/ s12134-018-0566-0.

Ibrahim, Ibnor Azli, Mohd Nur Hidayat Hasbollah Hajimin, Ezad Azraai Jamsari, Badlihisham Mohd Nasir, and Mohd Hafiz Safiai. "The Impact of Filipino Muslim Ethnic Migration into Sabah on ASEAN Integration." International Journal of Innovative Technology and Exploring Engineering 8, no. 11 (2019): 369372. https://doi.org/10.35940/ijitee.k1354.0981119.

Kurus, Bilson. "Migrant labor: The Sabah experience." Asian and Pacific Migration Journal 7, no. 2-3 (1998): 281-294. https://doi.org/10.1177/011719689800700208.

Testaverde, Mauro, Harry Moroz, Claire H. Hollweg, and Achim Schmillen. Migrating to opportunity: overcoming Barriers to Labor Mobility in Southeast Asia. Washington, D.C.: The World Bank, 2017. https:// openknowledge.worldbank.org/handle/10986/28342. 


\section{Bibliography}

Abubakar, Carmen A. "A never-ending war and the struggle for peace in southern Philippines." In Islam and Politics in Southeast Asia, edited by Johan Saravanamuttu, 143-159. Routledge, 2009.

Addison, Tony, and S. Mansoob Murshed. "Transnational terrorism as a spillover of domestic disputes in other countries." Defence and Peace Economics 16, no. 2 (2005): 69-82.

Balasubramaniam, Vejai. "A divided nation: Malay political dominance, Bumiputera material advancement and national identity in Malaysia." National Identities 9, no. 1 (2007): 35-48. https://doi.org/10.1080/10242690500070078.

Bedi, Rashvinjeet S. "One in five Malaysian undergrads feel terrorism an effective tool for achieving objectives, say survey." The Star Online, July 27, 2018. https://www.thestar.com.my/news/nation/2018/07/27/ one-in-five-msian-undergrads-feel-terrorism-effective-tool-for-achieving-objectives/.

Berger, J. M. Making CVE Work: A Focused Approach Based on Process Disruption. International Centre for Counter-terrorism- The Hague, 2016. http://dx.doi.org/10.19165/2016.1.05.

Carruthers, Andrew M. Clandestine Movement in the Indonesia-Malaysia Migration Corridor: Roots, Routes, and Realities. ISEAS Yusof Ishak Institute, 2017. http://hdl.handle.net/11540/7362.

Chalk, Peter. "Contemporary maritime piracy in Southeast Asia," Studies in Conflict \& Terrorism 21, no. 1 (1998): 87-112. https:// doi.org/10.1080/10576109808436055.

Chan, Nicholas. "The Malaysian 'Islamic' State versus the Islamic State (IS): evolving definitions of 'terror,' in an 'Islamising' nationstate." Critical Studies on Terrorism 11, no. 3 (2018): 415-437. https://doi.org/10.1080/17539153.2018.1447217.

Cruz De Castro, Renato. "The Influence of Transnational Jihadist Ideology on Islamic Extremist Groups in the Philippines: The Cases of the Abu Sayyaf Group and the Rajah Solaiman Movement." Public Organization Review 3, no. 4 (2003): 388.

Dollah, Ramli, Wan Shawaluddin Wan Hassan, Diana Peters, and Zaini Othman. "Old Threats, New Approach and National Security in Malaysia: Issues and Challenges in Dealing with Cross-border Crime in East Coast of Sabah." Mediterranean Journal of Social Sciences 7, no. 3 (2016): 178-186. https://doi.org/10.5901/mjss.2016.v7n3s1p178.

Fuller, Thomas. "20 Kidnapped from Malaysian Resort Island." The New York Times, April 25, 2000. https://www.nytimes. com/2000/04/25/news/20-kidnapped-from-malaysian-resort-island.html.

Global Terrorism Database (GTD). The National Consortium for the Study of Terrorism and Responses to Terrorism (START) at the University of Maryland, College Park. Accessed August 15, 2021. https://start.umd.edu/gtd/.

Henkin, Samuel, Hafiza Nur Adeen Nor Ahmad, Ramli Dollah, Wan Shawaluddin Wan Hassan, Jagroop Singh, and Ahmad el-Muhammady. Divergent Dimensions of Radicalization Risk: Migration and Violent Extremism in Sabah, Malaysia, Desk Study Report to the Bureau of Conflict and Stabilization Operations, U.S. Department of State. College Park, MD: START, 2021. https://www. start.umd.edu/publication/divergent-dimensions-radicalization-risk-migration-and-violent-extremism-sabah-malaysia.

Henkin, Samuel, Marcus A. Boyd, and Adam Martin. "Southeast Asia After the Caliphate: Identifying Spatial Trends in Terrorism and Radicalization in Malaysia." Statistics, Politics and Policy (2020). https://doi.org/10.1515/spp-2020-0001.

Hume, Elizabeth, and Emily Myers. Peacebuilding Approaches to Preventing and Countering Violent Extremism: Assessing the evidence for key theories of change. Washington, D.C.: Alliance for Peacebuilding, 2018. https://allianceforpeacebuilding. squarespace.com/afp-publications/peacebuilding-approaches-to-4-2018.

Ibrahim, Ibnor Azli, Mohd Nur Hidayat Hasbollah Hajimin, Ezad Azraai Jamsari, Badlihisham Mohd Nasir, and Mohd Hafiz Safiai. "The Impact of Filipino Muslim Ethnic Migration into Sabah on ASEAN Integration." International Journal of Innovative Technology and Exploring Engineering, 8, no. 11 (2019): 369-372. https://doi.org/10.35940/ijitee.k1354.0981119. 
Jayakumar, Shashi. "The Islamic State Looks East: The Growing Threat in Southeast Asia." CTC Sentine/ 22 (2017). https://www.ctc. usma.edu/the-islamic-state-looks-east-the-growing-threat-in-southeast-asia/.

"Malaysian police kill suspected Philippine militants," The Strait Times, May 18, 2021, https://www.straitstimes.com/asia/se-asia/ malaysian-police-kill-suspected-philippine-militants.

Mastroe, Caitlin, and Susan Szmania. Surveying CVE Metrics in Prevention, Disengagement, Deradicalization Programs. College Park, MD: National Consortium for the Study of Terrorism and Responses to Terrorism, 2016. https://www.start.umd.edu/ pubs/START SurveyingCVEMetrics March2016.pdf.

Mohamed, Mohd Kassim Noor. "Kidnap for Ransom in South East Asia." Asian Journal of Criminology 3, no. 1 (2008): 61-73. https:// doi.org/10.1007/s11417-007-9040-1.

Osman, Mohamed Nawab Mohamed, and Aida Arosoai. "Jihad in the Bastion of 'Moderation': Understanding the Threat of ISIS in Malaysia." Asian Security 16, no. 1 (2019), 1-14. https://doi.org/10.1080/14799855.2018.1470508.

Raj, Andrin J. N. "Challenges in counter terrorism and counter violent extremism in Malaysia." In Countering Insurgencies and Violent Extremism in South and South East Asia, edited by Shanthie Mariet D'Souza, 207-222. New York: Routledge, 2019.

Ramakrishna, Kumar. "The Southeast Asian Approach' to Counter-Terrorism: Learning from Indonesia and Malaysia." The Journal of Conflict Studies. 25, no. 1 (2005): 27-47. https://journals.lib.unb.ca/index.php/JCS/article/download/189/333?inline=1.

Rodzi, Nadirah H. "Kuala Lumpur says foreign militants eyeing Malaysia as safe haven." The Strait Times, March 11, 2019. https:// www.straitstimes.com/asia/se-asia/kl-says-foreign-militantseyeing-malaysia-as-safe-haven.

Schulze, Kristen E., and Julie Chernov Hwang. "Militant Islam in Southeast Asia: New Insights into Jihad in Indonesia, Malaysia and the Philippines." Contemporary Southeast Asia 41, no. 1 (2019): 4. https://doi.org/10.1355/cs41-1a.

Smith, Paul J. (ed.) Terrorism and Violence in Southeast Asia: Transnational Challenges to States and Regional Stability. London: Routledge, 2005.

Storey, Ian. Trilateral Security in the Sulu-Celebes Seas: A Work in Progress. ISEAS Yusof Ishak Institute, 2018. https://www.iseas. edu.sg/images/pdf/ISEAS Perspective 2018 48@50.pdf.

Testaverde, Mauro, Harry Moroz, Claire H. Hollweg, and Achim Schmillen. Migrating to opportunity: overcoming Barriers to Labor Mobility in Southeast Asia. Washington, D.C.: The World Bank, 2017. https://openknowledge.worldbank.org/ handle/10986/28342.

Ugarte Eduardo F., and Mark Macdonald Turner. "What Is the 'Abu Sayyaf'? How Labels Shape Reality." The Pacific Review 24, no. 4 (2011): 397-420. https://doi.org/10.1080/09512748.2011.596558.

Wolfendale, Jessica. "Terrorism, Security, and the Threat of Counterterrorism." Studies in Conflict \& Terrorism 30, no. 1 (2007): 75-92. https://doi.org/10.1080/10576100600791231.

Ying, Teoh Pei. "12Filipinos, oneMalaysianterrorsuspectsnabbedinSabahcrackdown." NewStraits Times, March18, 2019. https://www. nst.com.my/news/crime-courts/2019/03/470376/12-filipinos-one-malaysian-terror-suspects-nabbed-sabah-crackdown.

Yong, Joseph Chin. Piety and politics: Islamism in contemporary Malaysia. Oxford University Press, 2009. https://doi.org/10.1093/ acprof:oso/9780195377088.001.0001. 


\section{About the Note}

Author: Samuel Henkin, Ph.D., is a Senior Researcher in the Geospatial Research Unit at the National Consortium for the Study of Terrorism and Responses to Terrorism (START) at the University of Maryland, College Park (UMD). He also serves as a professor in UMD's undergraduate Terrorism Studies Minor and the Master of Professional Studies in Security and Terrorism Studies programs. Dr. Henkin is a political geographer whose expertise exists at the intersection of the geographies of political violence, violent extremism in Southeast Asia, national security policy, and preventing and countering violent extremism (P/CVE) capacity building.

The views expressed in this publication are those of the author. They do not necessarily reflect the views of the RESOLVE Network, the U.S. Institute of Peace, or any entity of the U.S. government.

RESOLVE NETWORK

better research.informed practice.improved policy on violent extremism. www.resolvenet.org 